\title{
gPERANAN BAHAN/SISA ORGANIK LAIN SEBAGAI PENGGANTI TOP SOIL TEHADAP KEBERHASILAN REKLAMASI/REVEGETASI DI WILAYAH BEKAS TAMBANG BAUKSIT PT ANTAM TbK UBP BAUKSIT KALIMANTAN BARAT ${ }^{1}$
}

\author{
Umar Bahidin \\ Environment Assistant Manager, Departemen Lingkungan, Biro Health, Safety and Environment \\ PT ANTAM Tbk UBP Bauksit
}

\begin{abstract}
ABSTRAK
Top Soil masih memegang peranan penting untuk menunjang keberhasilan kegiatan reklamasi/revegetasi pada areal bekas tambang, khususnya pertambangan terbuka (open pit/cast). Lapisan/layer top soil yang relatif tipis/sedikit membuat kegiatan reklamasi/revegetasi menjadi tidak maksimal. Diperlukan bahan/sisa organik lain sebagai alternatif untuk menggantikan fungsi/peran top soil untuk memperbesar persentasi keberhasilan kegiatan reklamasi/revegetasi. Penelitian ini bertujuan untuk mengetahui sejauh mana peran dari bahan/sisa organik lain untuk membantu memperbaiki kualitas lahan di areal bekas tambang bauksit. Penelitian dilakukan dari mulai dari tahun 2017 sampai dengan tahun 2019, di areal reklamasi PT ANTAM Tbk UBP Bauksit, Kecamatan Tayan Hilir, Kabupaten Sanggau, Provinsi Kalimantan Barat. Metode yang digunakan adalah pembuatan dem plot ukuran $20 \mathrm{~m}$ x 6m dengan kolom 1 (satu) sebagai kontrol (areal tanah asli/bekas tambang), kolom 2 (dua) untuk TKKS, Kolom 3(tiga) dengan Serasah, serta Kolom 4 (empat) dengan top soil. Keempat kolom tersebut untuk melihat sejauhmana tingkat pertumbuhan tanaman pokok (jambu hutan dan Jambu mete) dan Legume Cover Crop (LCC) dengan menggunakan perlakuan tersebut. Analisa sifat fisik kimia tanah juga dilakukan untuk mengetahui kandungan dari tiap-tiap bahan/sisa organik lain yang kemudian dibandingkan dengan top soil. Hasil penelitian menunjukkan bahwa bahan/sisa organik lain dapat memberikan konstribusi positif pada areal reklamasi/revegetasi, dengan meningkatkan percepatan pertumbuhan cover crop dan tanaman pokok. Hasil penelitian juga saat ini sudah diaplikasikan untuk kegiatan reklamasi/revegetasi PT ANTAM Tbk UBP Bauksit mulai dari tahun 2018 sampai dengan saat ini.
\end{abstract}

Kata kunci : Top Soil, bahan/sisa organik lain, bekas tambang bauksit, open pit/cast, reklamasi, revegetasi, Jambu Hutan, Jambu Mete, LCC.

\begin{abstract}
Top Soil still plays an important role to support the success of reclamation/revegetation activities in mine out areas, especially open pitcast mining. Top soil layers that are relatively thins/lightly make reclamation/revegetation activities not optimal. Other organic materials/waste is needed as an alternative to replace the function/role of top soil to increase the percentage of successful reclamation/revegetation activities. This study aims to determine the extent of the role of other organic materialswaste to help improve the quality of land mine out areas. The study was conducted from 2017 to 2019, in the reclamation area of PT ANTAM Tbk UBP Bauksit, Tayan Hilir District, Sanggau Regency, West Kalimantan Province. The method used is making a demonstration plot of $20 \mathrm{~m} \times 6 \mathrm{~m}$ size with column 1 (one) as a control (original / mine out area), column 2 (two) for TKKS Treatment, Column 3 (three) for Serasah Treatment, and Column 4 (four) with top soil. The four columns are to see the extent of growth of staple plants (local guava and Cashew) and Legume Cover Crop (LCC) using these treatments. Analysis of soil chemical physical properties was also carried out to determine the content of each other organic material /waste
\end{abstract}


which was then compared with top soil. The results showed that other organic materials/waste can make a positive contribution to the reclamation / revegetation area, by increasing the acceleration of cover crop growth and staple crops. The results of the study have also been applied for the reclamation/revegetation activities of PT ANTAM Tbk UBP Bauxite starting from 2018 until now.

Keywords: Top Soil, other organic materials /waste, bauxite mining, mine out, open pit/cast, reclamation, revegetation, Local Guava, Guava, LCC, Cashew

\section{A. PENDAHULUAN}

\section{A.1. Latar Belakang}

Sebagai bagian dari proses penambangan, kegiatan reklamasi/revegetasi memerlukan perencanaan yang tepat serta mampu memberikan hasil yang optimal pada saat proses penilaian oleh pihak pemerintah. Untuk mencapai hasil yang optimal, perlu diketahui variabel-variabel yang berperan penting untuk mendukung keberhasilan kegiatan reklamasi/revegetasi. Beberapa variabel tersebut adalah ketersediaan top soil, kesuburan tanah, pemilihan jenis tanaman dan sebagainya.

Top Soil masih memegang peranan penting untuk menunjang keberhasilan kegiatan reklamasi/revegetasi pada areal bekas tambang, khususnya pertambangan terbuka (open pit/cast). Namun pada beberapa lokasi berdasarkan karakteristik geografis wilayah, terdapat lapisan/layer top soil yang relatif tipis/sedikit membuat kegiatan reklamasi/revegetasi menjadi tidak maksimal. Sehingga pada proses regrading/penataan lahan, masih tidak optimal pada saat melakukan covering top soil pada areal bekas tambang (mine out).

Beberapa alternatif bahan organik diidentifikasi berada diwilayah Izin Usaha Pertambangan (IUP) PT ANTAM Tbk UBPB Kalimantan barat berupa sisa organik dari pengolahan TBS (Tandan Basah Sawit) berupa Tandan Kosong Kelapa Sawit (TKKS) serta serasah (tumpukan sisa daun kering/mati, ranting, dan sisa vegetasi lainnya yang membentuk lantai hutan). Namun perlu diketahui efektifitas dari bahan-bahan organik tersebut diatas untuk membantu memberikan peran optimal pada saat proses reklamasi/revegetasi.

\section{A.2. Tujuan}

Keterbatasan top soil, perlu diatasi dengan mencari alternatif untuk membantu atau mensubtitusi peran dari top soil. Diperlukan bahan/sisa organik lain sebagai alternatif untuk menggantikan fungsi/peran top soil untuk memperbesar persentasi keberhasilan kegiatan reklamasi/revegetasi. Perlu digarisbawahi bahwa, hanya peran dari top soil serta karakteristik unsur hara saja yang perlu untuk dicari alternatifnya, sehingga tujuan dari penelitian ini adalah :

1) Mengetahui sifat fisik kimia tanah pada TKKS dan Serasah untuk mendukung keberhasilan reklamasi/revegetasi

2) Mengetahui keberhasilan pertumbuhan tanaman ketika dilakukan uji coba dengan menggunakan sisa bahan organik tersebut.

\section{A.3. Pendekatan Pemecahan Masalah}

Tujuan tersebut dapat dilakukan pendekatan eksperimental dengan uji coba dilapangan sehingga dapat diketahui sejauhmana tingkat keberhasilan pertumbuhan tanaman dengan menggunakan TKKS, Serasah dan Top Soil.

\section{B. METODOLOGI PENELITIAN}

Penelitian ini dilaksanakan pada bulan Juli 2017 sampai dengan Bulan Juli 2019. Pengambilan data primer dilaksanakan pada areal reklamasi bukit 7A, WIUP PT ANTAM Tbk UBPB Kalimantan 
Barat. Penelitian ini dilakukan pada petak demonstration plot (demplot) yang telah dibuat dengan luas $20 \times 8$ meter.

Demplot yang telah dibuat kemudian diberikan perlakuan 3 jenis bahan organik penutup tanah berupa Top Soil, TKKS dan Serasah ditambahn satu kontrol berupa tanah asli bekas tambang. Metode yang digunakan dalam penelitian ini adalah metode deskriptif dengan pendekatan kualitatif secara sederhana, dimana hasil pertumbuhan dicatat variabel-variabel pertumbuhannya. Adapun variabel yang dicatat berupa tinggi tanaman dan lebar tajuk. Untuk hasil analisa sifat fisik kimia pada setiap bahan organik akan akan disajikan secara kualiatif untuk membandingkan parameterparameter kesuburan tanah. Penelitian status tinggi atau rendahnya unsur hara dari bahan organik akan menggunakan kriteria Penilaian dari Pusat Penelitian Tanah (PPT).

Untuk perlakuan setiap tanaman, diberikan pupuk yang berasal dari bahan organik (TKKS, Serasah dan Top Soil) dengan dosis $4 \mathrm{Kg}$ perlubang tanam. Serta tanaman kontrol yang diberikan pupuk kandang dengan dosis yang sama. Pada arela permukaan dari masing-masing perlakuan, diberikan hamparan dari setiap bahan organik sesuai dengan perlakukannya dengan ketebalan antara 6-15 $\mathrm{cm}$.

\section{HASIL DAN PEMBAHASAN}

\section{C.1. Sifat fisik kimia pada setiap bahan organik}

Dari hasil analisa laboratorium, kandungan sifat fisik kimia pada setiap bahan organik dapat dilihat pada tabel berikut :

Tabel 1. Sifat fisik kimia dari Masing-Masing Bahan Organik

\begin{tabular}{cllccc}
\hline \multirow{2}{*}{ No Parameter } & \multirow{2}{*}{ Satuan } & \multicolumn{3}{c}{ Bahan Organik } \\
\cline { 4 - 6 } & & & Serasah & Tangkos & Top Soil \\
\hline 1 & Tekstur : & $\%$ & 0 & 47.66 & 27.65 \\
& -Pasir & $\%$ & 14.84 & 28.99 & 70.49 \\
& -Debu & $\%$ & 85.16 & 23.35 & 1.86 \\
& -Liat & - & 3.74 & 8.3 & 5.52 \\
2 & pH H2O & $\%$ & 9.65 & 10.33 & 2.42 \\
3 & C-Organik & $\%$ & 0.141 & 0.876 & 1.61 \\
4 & N Total & $\%$ & 0.486 & 0.224 & $<0.001$ \\
5 & P Tersedia & meq/100gr & 1.18 & 12.1 & 0.07 \\
6 & Kation dapat ditukar K & meq/100gr & 0.127 & 0.132 & 0.104 \\
7 & Kation dapat ditukar Na & meq/100gr & 1.28 & 3.41 & 0.239 \\
8 & Kation dapat ditukar Ca & meq/100gr & 0.18 & 0.188 & 0.098 \\
9 & Kation dapat ditukar Mg & meq/100gr & 62.2 & 27.7 & 7.12 \\
10 & Kapasitas Tukar Kation (KTK) & mennyyyy
\end{tabular}

Tekstur pada masing-masing bahan organik memperlihatkan perbedaan-perbedaan komposisi yang khas, dimana pada serasah didominasi oleh liat, kemudian untuk top soil didominasi oleh debu, sementara untuk TKKS didominasi oleh pasir. Sebaran tekstur dapat mempengarui kandungan bahan organik serta kemampuan untuk menyerap dan menyimpan air.

Menurut Lubis, dkk (2015), $\mathrm{pH}$ tanah sangat berpengaruh dalam pertumbuhan tanaman, seperti ketersediaan unsur hara, pembentukan bintil akar oleh bakteri rhizobiumyang berhubungan dengan fiksasi $\mathrm{N}$ tanaman, juga aktifitas pertumbuhan perkembangan dan populasi rhizobium. Dari hasil analisa, TKKS memiliki nilai $\mathrm{pH}$ yang bersifat basa dibanding top soil dan Serasah. Dari hasil analisa, TKKS memiliki $\mathrm{pH} \mathrm{H}_{2} \mathrm{O}$ yang lebih baik dari bahan organik lain. 


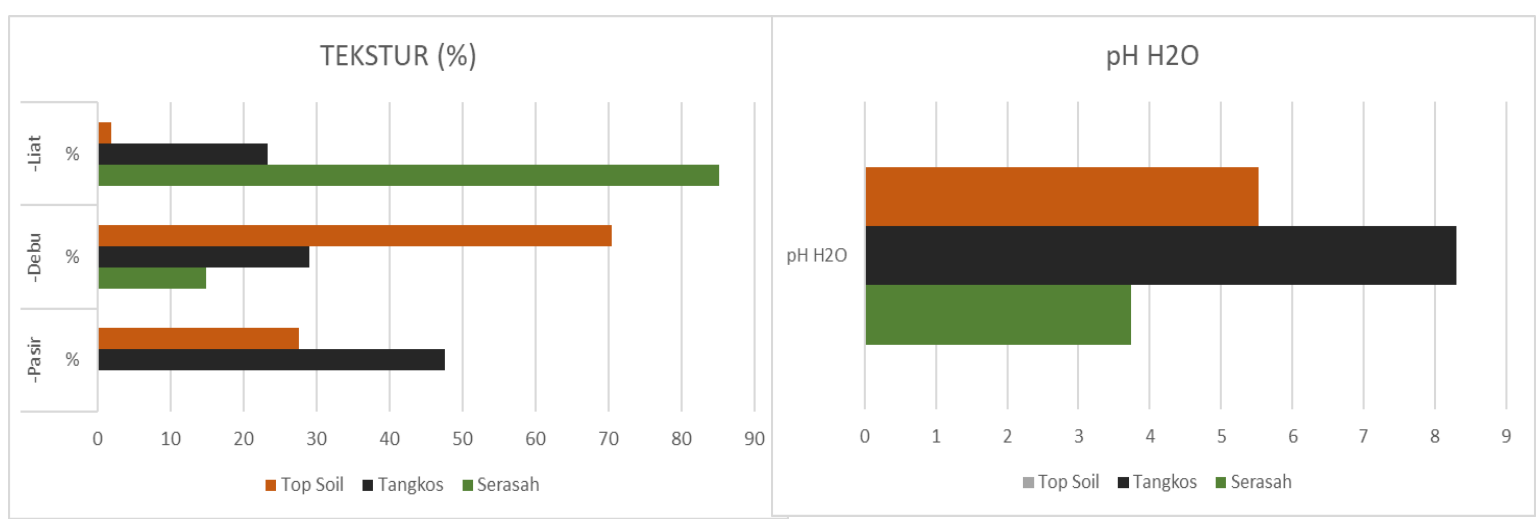

Gambar 1. Analisa tekstur pada tiap bahan organik dan $\mathrm{pH}_{2} \mathrm{O}$

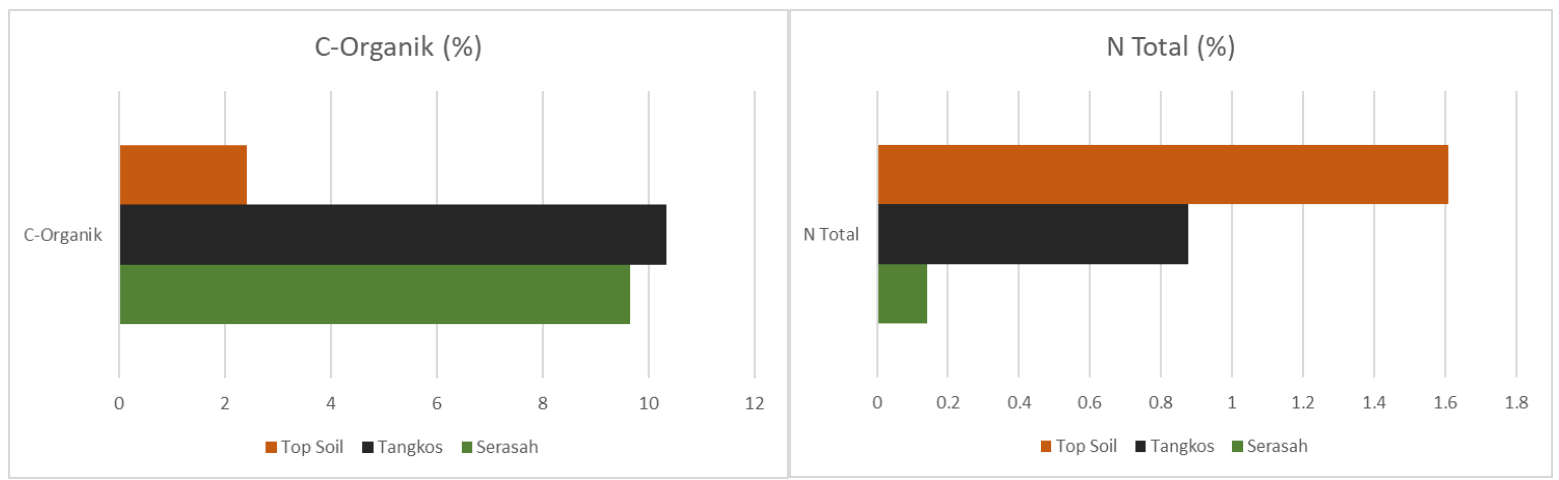

Gambar 2. Analisa C-Organik pada tiap bahan organik dan N Total

Hasil analisa C-Organik menunjukkan bahwa TKKS dan Serasah memiliki nilai yang sangat tinggi bila mengacu pada kriteria dari PPT Bogor. Dimana nilai C-Organik dari TKKS dan Serasah melebihi nilai 5\% sehingga masuk kategori sangat tinggi (ST) sementara Top Soil berada pada kriteria sedang (S). Mustofa (2007) dalam Barek (2013) dalam Azmul, dkk (2016) dalam penelitiannya menyatakan bahwa kandungan bahan organik dalam bentuk C-Organik tanah harus dipertahankan tidak kurang dari $2 \%$. C-Organik dipercaya sebagai kunci ketahanan terhadap kekeringan dan kelestarian produksi pangan.

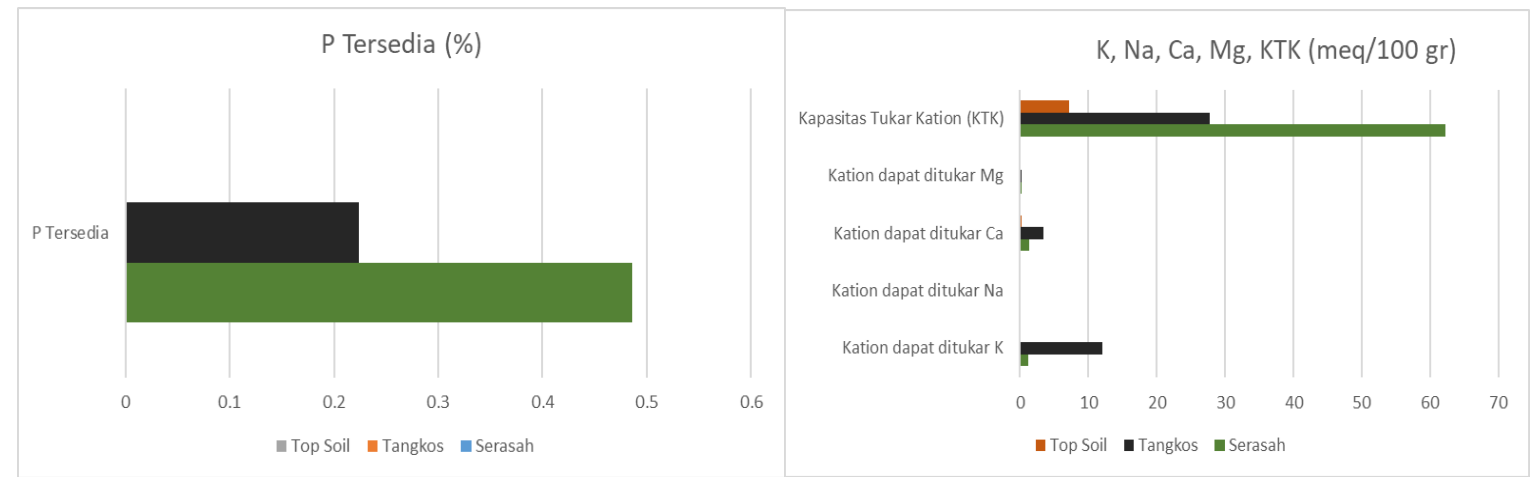

Gambar 3. Analisa P Tersedia dan Kation-kation pada tiap bahan organik

Nitrogen $(\mathrm{N})$ dan Fosfor $(\mathrm{P})$ merupakan unsur hara yang sangat dibutuhkan oleh tanaman dalam jumlah yang besar. Nitrogen merupakan anasir penting dalam pembentukan klorofil, protoplasma, protein, dan asam-asam nukleat. Unsur ini mempunyai peranan yang penting dalam pertumbuhan dan perkembangan semua jaringan hidup (Brady and Weil, 2002) dalam Fahmi, dkk (2010). 
Hasil analisa kandungan $\mathrm{P}$ total termasuk dalam kategori rendah $(\mathrm{R})$. Ketersediaan $\mathrm{P}$ sangat dipengaruhi oleh beberapa factor diantaranya $\mathrm{pH}$ tanah, adanya mineral yang megandung $\mathrm{Al}$, dekomposisi bahan organik dan kegiatan jasad renik (Laporan Kesuburan Tanah, 2017).

KTK merupakan sifat fisik kimia yang sangat erat hubungannya dengan kesuburan tanah. Bahan organik mempunyai daya serap kation yang lebih besar disbanding koloid liat, berarti semakin tinggi kandungan bahan organik suatu tanah maka semakin tinggi pula KTK nya (Hakim $d k k$., 1986 dalam Laporan Kesuburan Tanah, 2017). Dari hasil analisa, KTK pada serasah dapat dikategorikan sangat tinggi (ST) bila mengacu pada tabel PPT dengan nilai diatas 40 me/100 gr. Sementara untuk TKKS dalam kategori tinggi (T) dengan nilai 25-40 me/100 gr. Untuk top soil berada dalam kategori rendah $(\mathrm{R})$ dengan rentang nilai 5-15 me/100 gr.

\section{C.2. Tinggi tanaman pada setiap umur tanam}

Dari hasil pengamatan pada setiap umur tanam, dapat disimpulkan bahwa untuk perlakuan Top Soil, TKKS dan Serasah tidak memiliki perbedaan tinggi tanaman. Namun pada control, terdapat perbedaan tinggi tanaman, dimana tinggi tanaman menunjukan perbedaan tinggi rata-rata sebesar $43 \%$ dari tanaman dengan menggunakan bahan organik.

Tabel 2. Perbandingan rata-rata tingkat pertumbuhan tanaman Syzigium sp.

\begin{tabular}{|c|c|c|c|c|}
\hline & \multicolumn{4}{|c|}{ Tinggi Tanaman Syzigium Sp. (cm) } \\
\hline Umur & Serasah & Tankos & Top Soil & Kontrol \\
\hline Bulan ke-3 & 29.4 & 29.6 & 29.5 & 30.3 \\
\hline Bulan ke-6 & 56.3 & 58.4 & 59 & 43.3 \\
\hline Bulan ke-12 & 87.4 & 88.4 & 88 & 72.65 \\
\hline Bulan ke-24 & 139.7 & 140.4 & 139.6 & 93 \\
\hline
\end{tabular}

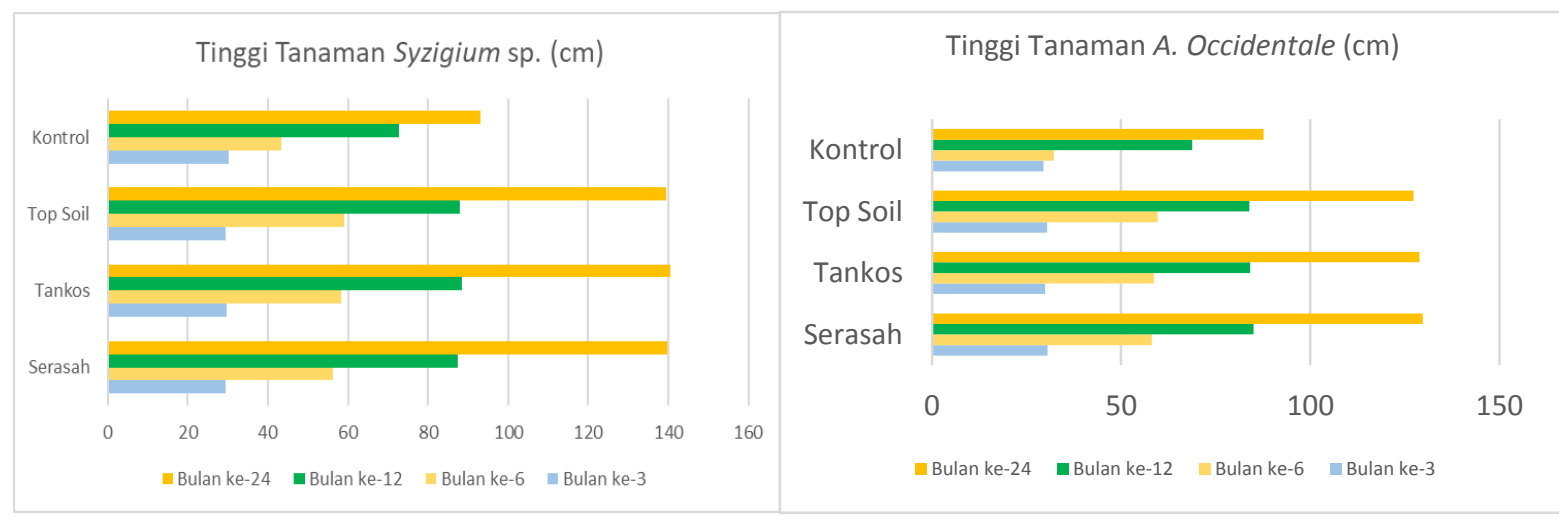

Gambar 4. Tinggi tanaman pada setiap umur tanam dari Jambu hutan dan jambu mete

Tabel 3. Perbandingan rata-rata tingkat pertumbuhan tanaman A. Occidentale

\begin{tabular}{lrrrr}
\hline \multicolumn{5}{c}{ Tinggi Tanaman A. Occidentale $(\mathbf{c m})$} \\
\hline & Serasah & \multicolumn{1}{c}{ Tankos } & \multicolumn{1}{c}{ Top Soil } & Kontrol \\
\hline Bulan ke-3 & 30.6 & 29.9 & 30.4 & 29.5 \\
Bulan ke-6 & 58.1 & 58.7 & 59.6 & 32.2 \\
Bulan ke-12 & 85 & 84.1 & 83.9 & 68.8 \\
Bulan ke-24 & 129.7 & 128.8 & 127.3 & 87.6 \\
\hline
\end{tabular}




\section{C.3. Lebar tajuk pada setiap umur tanam}

Tabel 4. Perbandingan Lebar Tajuk pada setiap umur tanam (Syzigium Sp.)

\begin{tabular}{lcccc}
\hline & \multicolumn{4}{c}{ Lebar Tajuk Syzygium Sp. $(\mathbf{c m})$} \\
\hline \multicolumn{1}{c}{ Umur Tanam } & Se rasah & Tankos & Top Soil & Kontrol \\
\hline Bulan ke-3 & 10.51 & 11.18 & 10.78 & 10.84 \\
Bulan ke-6 & 32.86 & 33.39 & 32.98 & 20.8 \\
Bulan ke-12 & 64.9 & 65.51 & 65.16 & 36.16 \\
Bulan ke-24 & 129.9 & 131 & 130.3 & 72.3 \\
\hline
\end{tabular}
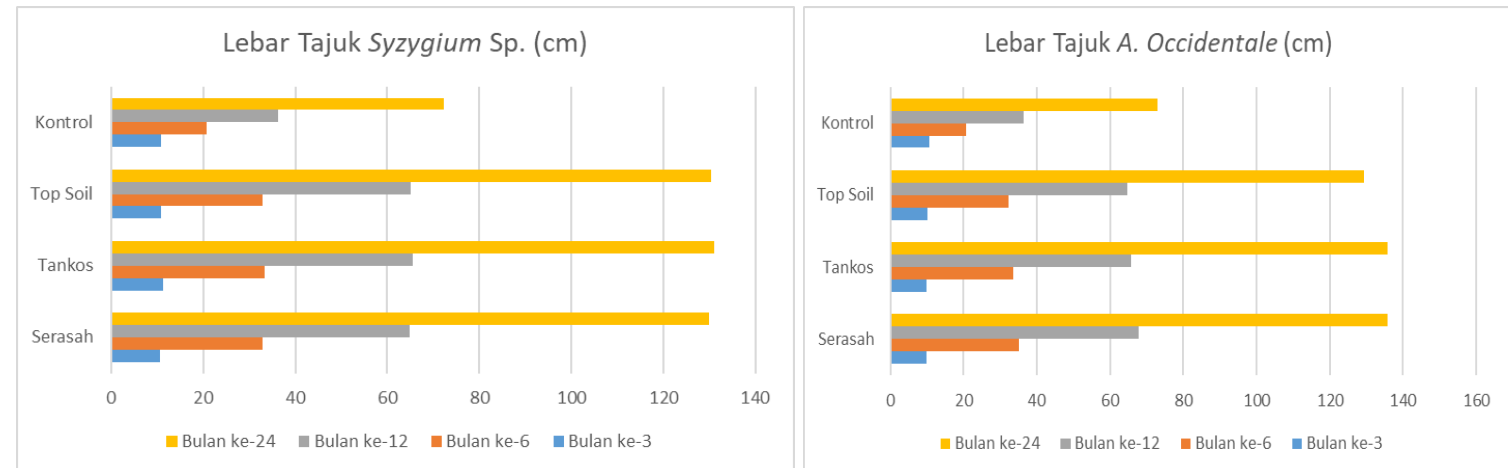

Gambar 7. Lebar tajuk Syzygium Sp.dan A. Occidentale pada setiap perlakuan

Tabel 5. Perbandingan Lebar Tajuk pada setiap umur tanam (A. Occidentale)

\begin{tabular}{lcccc}
\hline & \multicolumn{4}{c}{ Lebar Tajuk A. Occidentale $(\mathbf{c m})$} \\
\hline Umur Tanan & Serasah & Tankos & Top Soil & Kontrol \\
\hline Bulan ke-3 & 10.02 & 9.97 & 10.27 & 10.77 \\
Bulan ke-6 & 35.2 & 33.69 & 32.26 & 20.65 \\
Bulan ke-12 & 67.9 & 65.79 & 64.66 & 36.46 \\
Bulan ke-24 & 135.8 & 135.8 & 129.3 & 72.9 \\
\hline
\end{tabular}

\section{C.4. Perkembangan LCC (Legume Cover Crop)}

Pada setiap perlakukan diberikan LCC untuk membantu melakukan covering permukaan tanah, dimana LCC yang digunakan adalah jenis Pueraria Javanica. Dari hasil pengamatan, LCC menunjukkan hasil yang optimal untuk melakukan penutupan tanah. Oleh karena itu, bahan organik ini juga membantu mempercepat pertumbuhan LCC dan memperluas penutupan tanah untuk membantu memperbaiki sifat fisik dan kimia tanah.

\section{C.5. Kontribusi kegiatan kepada masyarakat setelah diaplikasikan}

Pada proses aplikasi dilapangan, kegiatan ini telah memberikan kontribusi kepada masyarakat lokal dengan memberikan kesempatan kerja dan berusaha dimana, masyarakat lokal dilibatkan secara langsung pada proses pengumpulan TKKS, dan pengumpulan serasah, serta melakukan kegiatan pemasangan TKKS dan penaburan serasah dilapangn. Adapun nilai yang telah diberikan dari tahun 2017 sd tahun 2019 dapat dilihat pada tabel 6 


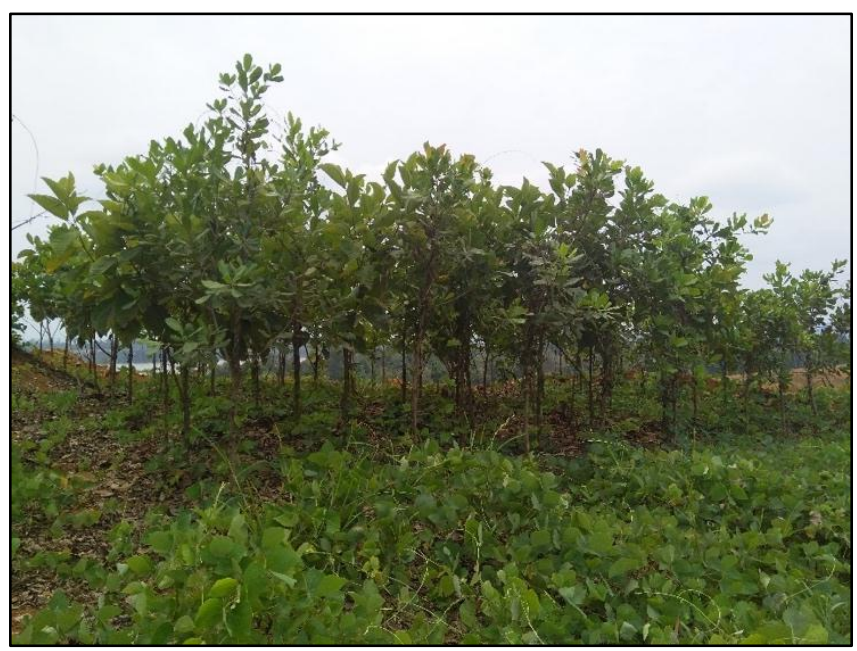

Gambar 8. Penutupan permukaah tanah dengan LCC

Tabel 6. Nilai kontrak pekerjaan TKKS dan Serasah kepada masyarakat

\begin{tabular}{cr}
\hline Tahun & Nilai Kontrak dengan Kelompok Masyarakat (Rp) \\
\hline 2017 & $2,647,430,988$ \\
2018 & $2,532,350,242$ \\
2019 & $1,904,202,447$ \\
\hline
\end{tabular}

\section{KESIMPULAN}

Penggunaan Serasah dan TKKS dapat membantu menggantikan peran dan fungsi dari top soil secara umum. Penambahan tinggi tanaman menunjukan perbedaan tinggi sekitar $43 \%$ dengan tanaman control, serta perbedaan lebar tajuk sebesar 55\% dengan tanaman kontrol. Masing-masing bahan organik memiliki karakteristik berbeda termasuk pula dengan kandunga unsur hara yang dimilikinya. Secara umum metode ini dapat diaplikasikan pada saat kegiatan

reklamasi/revegetasi. Hal ini juga dapat membantu perusahaan untuk mencari alternatif bahan organik lain untuk mengatasi persoalan klasik ayng dialami oleh perusahaan tambang yang menggunakan metode penambangan terbuka/open cast/open pit ketika masa reklamasi/revegetasi. Selain itu, bahan organik juga membantu meningkatkan keberhasilan pertumbuhan LCC.

Dari sisi pemberdayaan masyarakat, metode ini dapat memberikan kontribusi dan nilai tambah bagi kesejahteraan bagi warga sekitar IUP, dimana warga diberdayakan untuk dapat melakukan kegiatan mulai pada tahap pengumpulan bahan organik sampai dengan tahap pemasangan/penanaman.

\section{DAFTAR PUSTAKA}

Azmul., Yusran., dan Irmasari. (2016). Sifat Kimia Tanah Pada Berbagai Tipe Penggunaan Lahan Di Sekitar Taman Nasional Lore Lindu (Studi Kasus Desa Toro Kecamatan Kulawi Kabupaten Sigi Sulawesi Tengah). Warta Rimba. Vol 4. Nomor 2 24-31. Diperoleh melalui situs internet : https:// jurnal.untad.ac.id > jurnal > index.php > WartaRimba > article > download. Diunduh pada tanggal 26 September 2019 
Bab III. Metode Penelitian, diperoleh melalui situs internet: http://digilib.unila.ac.id/13594/3/BAB\%20III.pdf. Diunduh pada tanggal 10 september 2019

Fahmi, A., Syamsuddin., Utami, S., N., H., dan Radjagukguk, B. (2010). Pengaruh Interaksi Hara Nitrogen Dan Fosfor Terhadap Pertumbuhan Tanaman Jagung (Zea Mays L) Pada tanah regosol dan Latosol. Berita Biologi. Diperoleh melalui situs internet : https://media.neliti.com/media/publications/68518-ID-none.pdf Diunduh pada tanggal 26 September 2019

Lubis, D.S., Hanafiah, A.S., Sembiring, M. (2015). Pengaruh pH Terhadap Pembentukan Bintil Akar, Serapan Hara N, Pdan Produksi Tanaman pada Beberapa Varietas Kedelai pada Tanah Inseptisol Di Rumah Kasa. Jurnal Online Agroekologi. Vol 3. Nomor 3 1111-1115. Diperoleh melalui situs internet : https://media.neliti.com/media/publications/105432-IDpengaruh-ph-terhadap-pembentukan-bintil.pdf. Diunduh pada tanggal 26 September 2019

PT ANTAM Tbk UBPB Tayan. (2019). Laporan Kesuburan Tanah. Tayan. 27-38. 


\section{LAMPIRAN}

\section{Lampiran 1. Pembuatan Demplot}
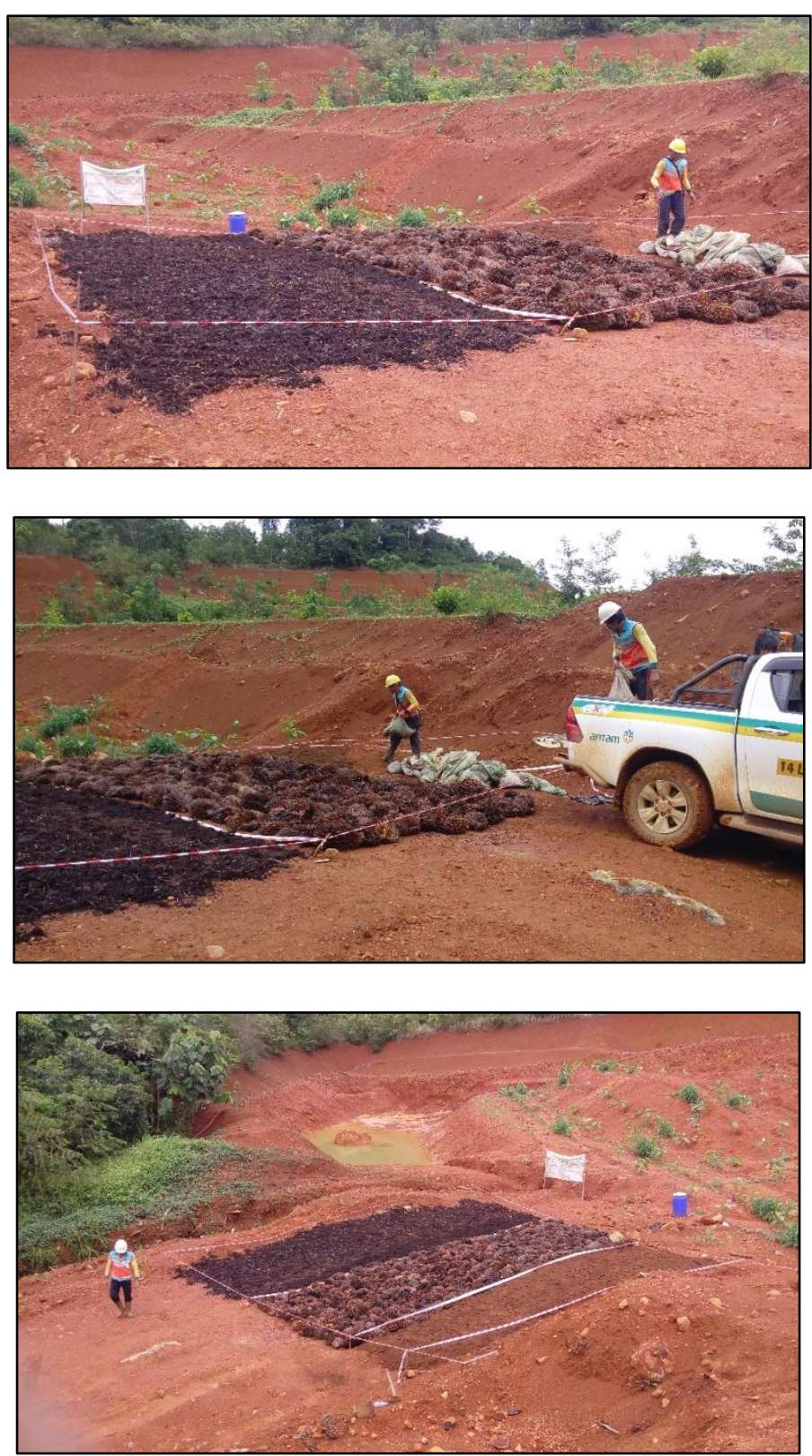


\section{Lampiran 2. Umur tanaman setelah 2 tahun}
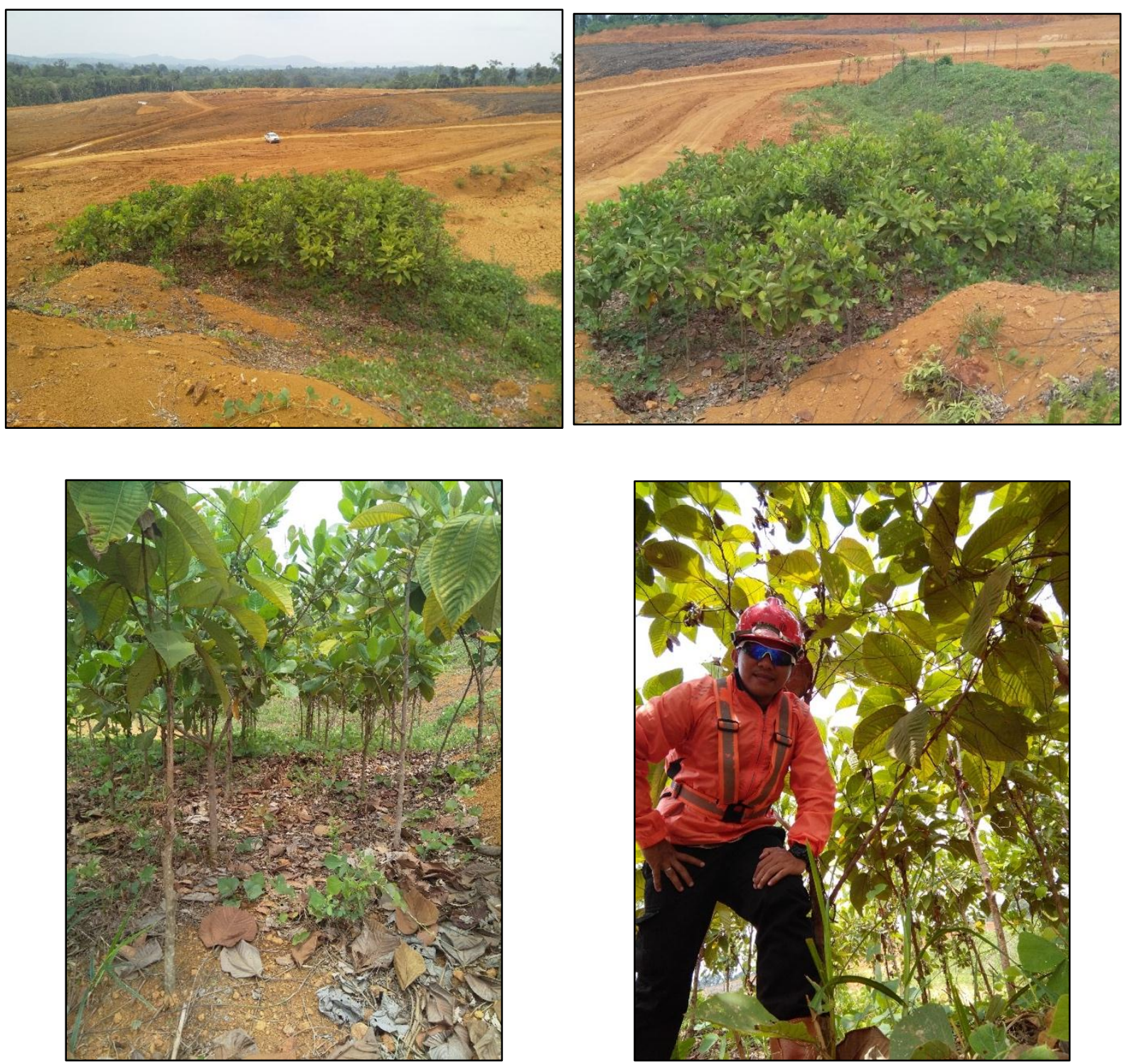


\section{Lampiran 3. Aplikasi diareal reklamasi/mine out}
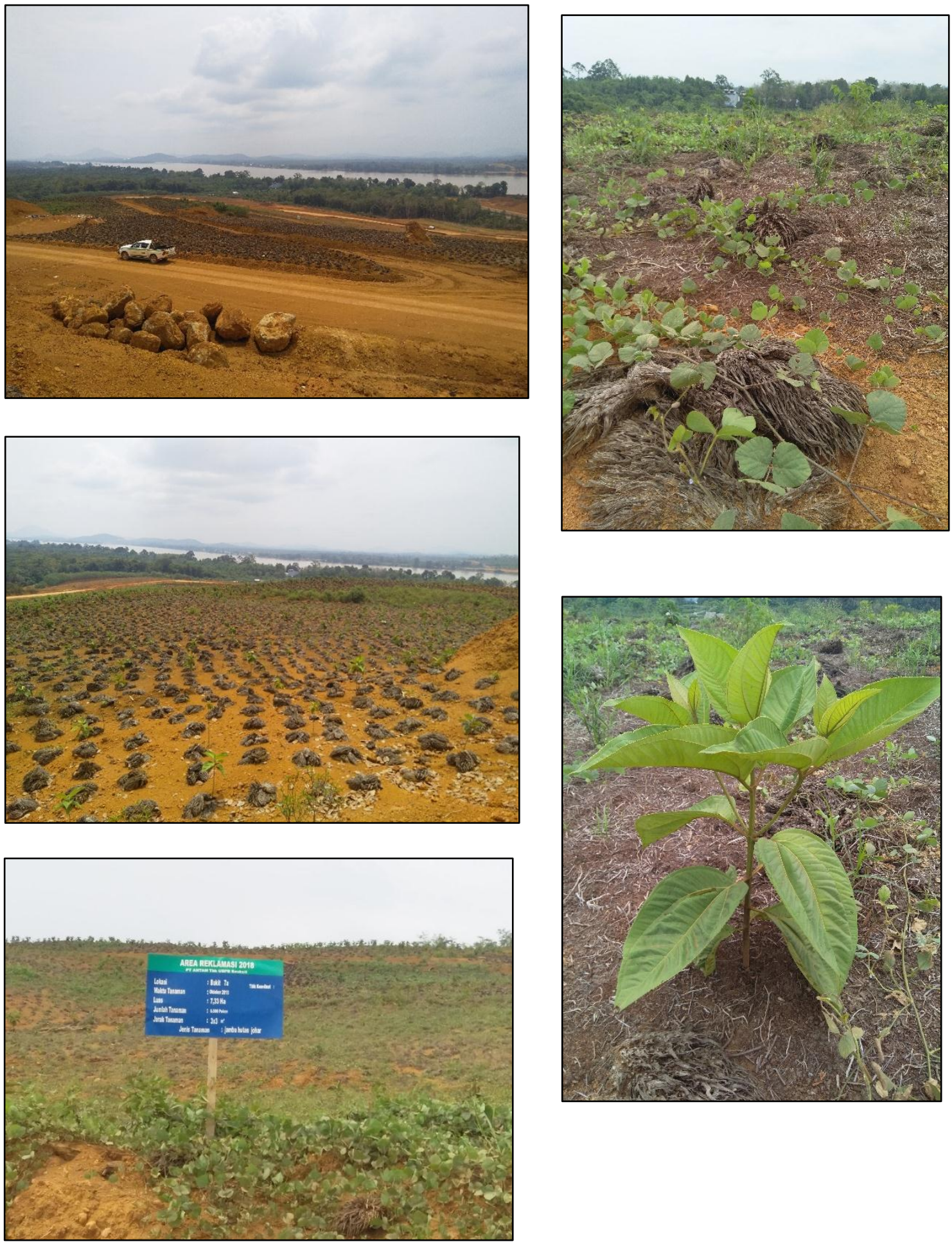
PROSIDING TPT XXVIII PERHAPI 2019 